\title{
Nitric Oxide-Mediated Transcriptional Changes in Arabidopsis thaliana
}

\author{
Annalisa Polverari, ${ }^{1}$ Barbara Molesini, ${ }^{1}$ Mario Pezzotti, ${ }^{1}$ Roberto Buonaurio, ${ }^{2}$ Mario Marte, ${ }^{2}$ \\ and Massimo Delledonne ${ }^{1}$
}

${ }^{1}$ Dipartimento Scientifico e Tecnologico, Università degli Studi di Verona, 37134 Verona, Italy; ${ }^{2}$ Dipartimento di Arboricoltura e Protezione delle Piante, Università degli Studi di Perugia, 06121 Perugia, Italy

Submitted 7 July 2003. Accepted 25 July 2003.

\begin{abstract}
Nitric oxide (NO) is an essential regulatory molecule in several developmental processes and in the stress response in both animal and plant systems. Furthermore, key features of plant resistance to pathogens have been shown to depend on NO production, e.g., defense gene expression and the activation of a hypersensitive reaction (HR) in synergy with reactive oxygen species (ROS). Due to the many possible mechanisms of NO action, a clear picture of its involvement in plant resistance to pathogens is far from being achieved. Transcriptional changes related to NO action are likely to play a significant role in resistance and cell death. We investigated the changes in the expression profiles of Arabidopsis thaliana following infiltration with the NO donor sodium nitroprusside, by cDNA-amplification fragment length polymorphism (AFLP) transcript profiling. Altered expression patterns were detected for 120 of the approximately 2,500 cDNAs examined. Sequence analysis revealed homologies with genes involved in signal transduction, disease resistance and stress response, photosynthesis, cellular transport, and basic metabolism or with sequences coding for unknown proteins. Comparison of the expression profiles with data from public microarray sources revealed that many of the identified genes modulated by NO were previously reported to be modulated in disease-related experiments.
\end{abstract}

Additional keywords: defense-related responses, programmed cell death.

Significant advances have been achieved in understanding the molecular basis of plant-pathogen interactions, especially in specific race-cultivar interactions (Bent 1996; de Wit 2002). A number of well-known defense-related responses follow pathogen recognition, including cell wall fortification, the production of antimicrobial molecules, the synthesis of pathogenesis related proteins (PRs), and often the activation of a hypersensitive reaction (HR) (Dangl and Jones 2001). The HR is manifested as a rapid cell death at the infection site that can be

Corresponding author: A. Polverari; E-mail: annalisa.polverari@univr.it; Telephone: +39 045 8027064; Fax: +39045 8027929.

* The $\boldsymbol{e}$-Xtra logo stands for "electronic extra" and indicates the HTML abstract available on-line contains a supplemental figure not included in the print edition.

This article is in the public domain and not copyrightable. It may be freely reprinted with customary crediting of the source. The American Phytopathological Society, 2003. triggered by a variety of pathogens and, to different extents, can contribute to effective resistance. Many examples have been well characterized in which the HR exhibits the features of programmed cell death (PCD) and has some aspects in common with animal apoptosis (Lam et al. 2001). Despite much research effort, the role of cell death in resistance is not yet completely clear; several examples in which resistance and cell death can be uncoupled (Bendahmane et al. 1999; Clough et al. 2000) or in which cell death does not seem to contribute to restriction of pathogen growth (Heath 2000) have been documented.

The molecular mechanisms associated with HR have been thoroughly investigated. The earliest observed events are variations in cytosolic calcium levels, protein phosphorylation/ dephosphorylation, activation of preexisting enzymes, and accumulation of reactive oxygen species (ROS) (Ebel and Mithöfer 1998). A strong biphasic production of ROS characterizes incompatible plant-pathogen interactions and has been shown to play multiple roles in plant defense (Lamb and Dixon 1997). ROS may be directly involved in pathogen killing and strengthening of plant cell walls, as well as in triggering hypersensitive cell death and in production of systemic resistance signals (Alvarez et al. 1998). For these reasons, ROS production has been considered a central event in activation of disease resistance. However, the precise role of ROS is still controversial, as an oxidative burst appears insufficient to trigger hypersensitive cell death (Glazener et al. 1996).

Nitric oxide (NO) has been identified as an essential molecule that mediates hypersensitive cell death and defense gene activation in plants (Delledonne et al. 1998; Durner et al. 1998). In animal cells, NO plays a fundamental role in cellular redox homeostasis in cooperation with ROS with consequences on a number of diverse physiological processes, including regulation of the immune and inflammatory response, apoptosis, and macrophage killing of bacteria (Schmidt and Walter 1994; Stamler et al. 1992). Recent findings indicate that NO determines cell death in cooperation with ROS, depending on the specific equilibrium between ROS and NO concentrations (Delledonne et al. 2001). Expression levels of the defense related genes phenylalanine ammonia lyase (PAL) and pathogenesis related protein PR-1 also rise following administration of NO donors or expression of recombinant NO-synthase in tobacco. These two genes are not inducible by $\mathrm{H}_{2} \mathrm{O}_{2}$ alone (Levine et al. 1994), indicating that $\mathrm{NO}$ and $\mathrm{H}_{2} \mathrm{O}_{2}$ have complementary functions in the activation of transcription dependent defenses. Finally, it has also been suggested that nitrosoglutathione could act as a long-distance phloematic signal in systemic acquired resistance (SAR) (Buonaurio et al. 2002; Durner and Klessig 1999), and recent data indicate that NO is required for the full function of salicylic acid (SA) as a SAR inducer (Song and Goodman 2001). NO signaling 
often operates in mammalian cells through cGMP- and cADPR-dependent pathways (Arnold et al. 1977; Wendehenne et al. 2001), and similar mechanisms are also active in plant disease resistance (Hausladen and Stamler 1998; Klessig et al. 2000). However, NO can also act on many other potential targets in the cell, directly or indirectly. This is especially true for metal- and thiol-containing proteins and enzymes, such as catalases and peroxidases (Clark et al. 2000), aconitase (Navarre et al. 2000), guanylate cyclase (Arnold et al. 1977), the salicylic-

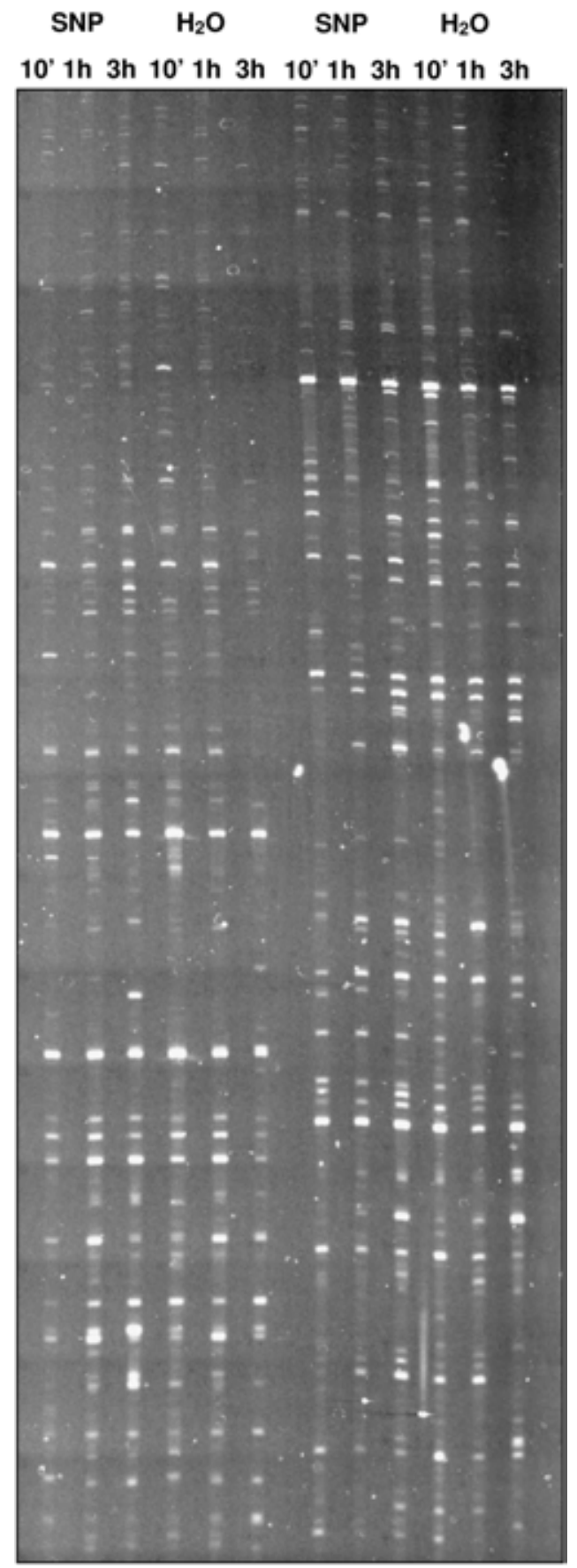

Fig. 1. cDNA-amplification fragment length polymorphism (AFLP) transcript profile of nitric oxide-induced changes of gene expression. Arabidopsis leaves were infiltrated with $1 \mathrm{mM}$ sodium nitroprusside (SNP) or distilled water and samples were collected at $10 \mathrm{~min}, 1$, and $3 \mathrm{~h}$ after treatment. A typical gel portion is reported, showing amplification products obtained with two different pairs of selective AFLP primers, visualized by fluorescent labeling of one primer. An average of 60 to 70 bands per lane were visualized on each gel, ranging from 50 to $450 \mathrm{bp}$ in size. induced protein kinase (Kumar and Klessig 2000), receptors, and transcription factors. Given the essential role of NO in resistance and hypersensitivity, it is likely that this highly reactive and diffusible molecule affects the transcription of a battery of genes related to defense. An important role for NO in regulating gene transcription has already been suggested by research in the medical field (Marshall et al. 2000; PinedaMolina et al. 2001) and might be extended to several different transcription factors.

To date, an extensive survey of the transcriptional changes induced by NO in plants has not been reported. The cDNAamplification fragment length polymorphism (AFLP) is a wellestablished, gel-based technique that allows comparison of gene expression profiles and can identify novel genes without previous sequence information (Bachem et al. 1996; Breyne and Zabeau 2001). In the present report, we use cDNA-AFLP transcription profile analysis (Breyne et al. 2002) to identify genes that are differentially expressed following exogenous application of a NO donor.

\section{RESULTS}

Induction of hypersensitive cell death by treatment with the NO donor sodium nitroprusside (SNP).

It has been shown previously that during the HR, NO cooperates with $\mathrm{H}_{2} \mathrm{O}_{2}$ to induce cell death from otherwise sublethal amounts of $\mathrm{H}_{2} \mathrm{O}_{2}$ (Delledonne et al. 2002). Therefore, NO donors trigger hypersensitive cell death when infiltrated in leaves exposed to high light in order to maintain a sufficient level of reactive oxygen intermediates (Belenghi et al. 2003). In the experimental conditions adopted, treatment with $1 \mathrm{mM}$ SNP caused a visible tissue collapse of infiltrated leaves about $24 \mathrm{~h}$ after treatment (data not shown). No symptoms were observed in water-infiltrated leaves.

\section{Detection of transcriptional changes following SNP treatment.}

Arabidopsis thaliana (Col-0) leaves were infiltrated with 1 mM SNP or with distilled water as a control. RNA was extracted $10 \mathrm{~min}, 1 \mathrm{~h}$, and $3 \mathrm{~h}$ after treatments and was subjected to cDNA-AFLP analysis. The cDNA-AFLP technique we adopted is an improved version of the original method (Bachem et al. 1996), developed to obtain a single cDNA fragment from each messenger RNA analyzed (Breyne et al. 2002, 2003). cDNA-AFLP reactions were performed with 32 primer combinations for selective amplification, with one selective base per primer (Bst YI-N/MseI-N). A portion of a typical

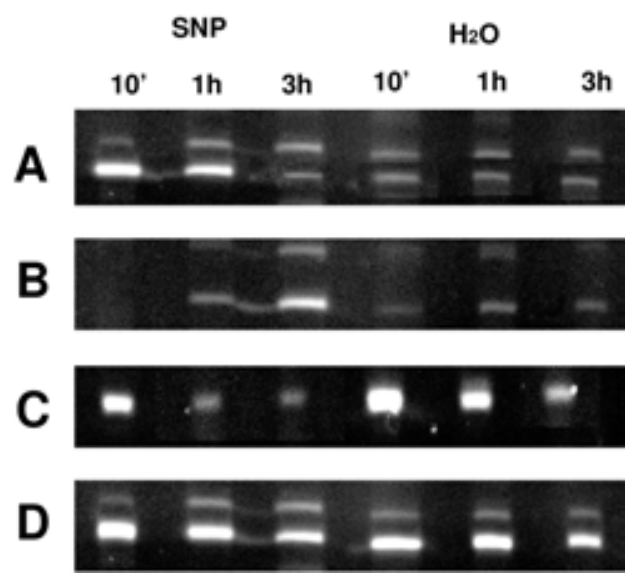

Fig. 2. Typical patterns of $\mathbf{A}$ and $\mathbf{B}$, induced, $\mathbf{C}$, repressed, and $\mathbf{D}$, nonmodulated genes in samples treated with $1 \mathrm{mM}$ sodium nitroprusside (SNP), compared with water infiltrated controls. 


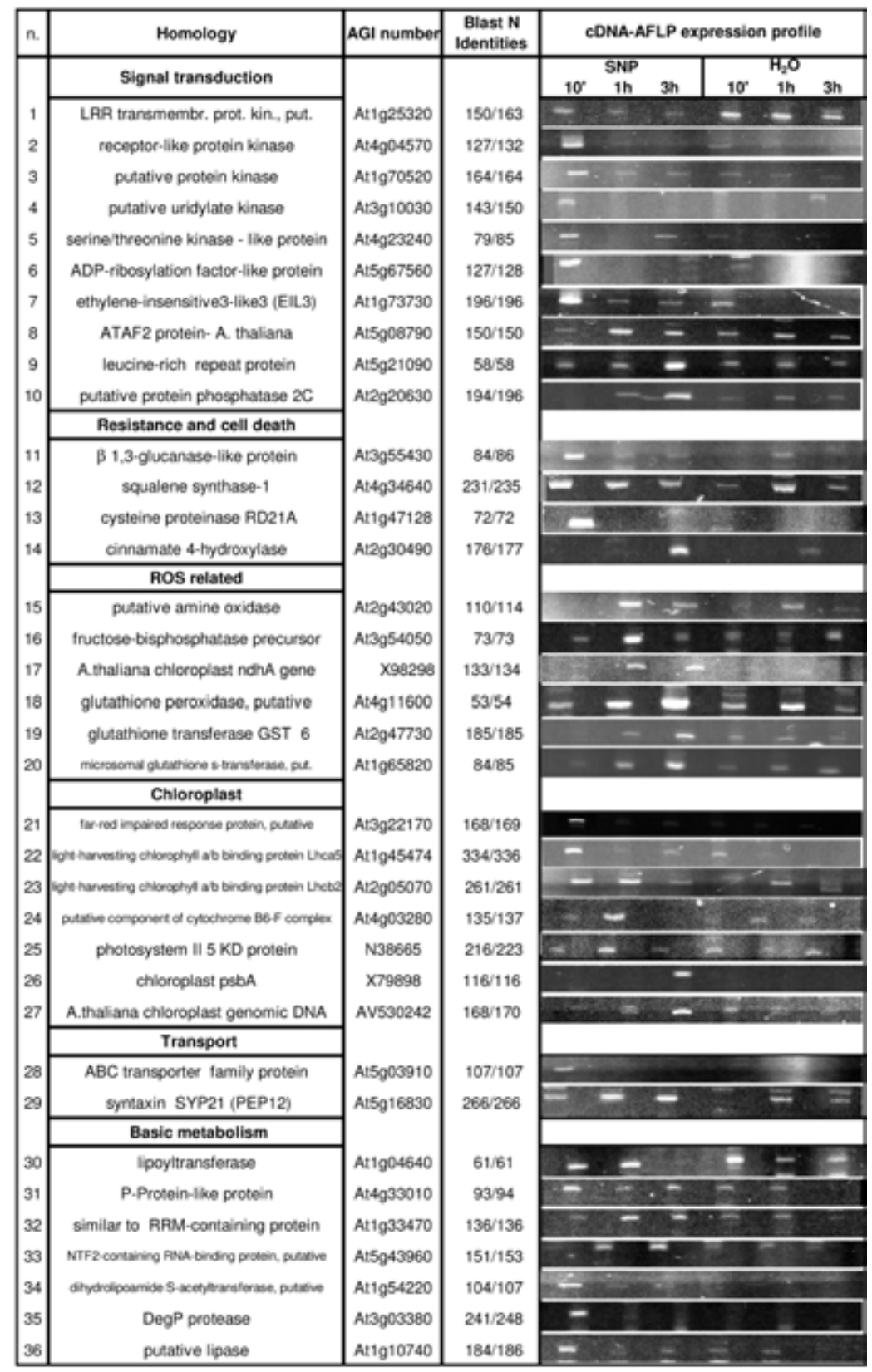

Fig. 3. Sequence homology, AGI number, nucleotide identities, and expression profiles of $71 \mathrm{cDNAs}$, differentially expressed after treatment with sodium nitroprusside, listed by putative functional category.

cDNA-AFLP electrophoresis profile is shown in Figure 1. AFLP fragments ranged from 50 to $450 \mathrm{bp}$; an average of 60 to 70 bands per lane was detected for each primer combination. Thus, it is estimated that about 2,500 different messenger RNAs have been visualized.

The majority of bands did not show a significant change in intensity in SNP-treated samples as compared with water-infiltrated controls. Figure 2 provides examples of typical patterns of induced (Fig. 2A and B), repressed (Fig. 2C), and nonmodulated (Fig. 2D) genes. Bands in all gels were visually scored and were analyzed further only when a strong increase or decrease in intensity was evident. Such levels of altered expression in response to SNP treatment were observed for 120 fragments. The large majority of transcripts affected by SNP treatment showed accumulation or were induced de novo, while only six transcripts appeared to be negatively modulated. The cDNA-AFLP profiles of all differentially expressed cDNAs are reported (Fig. 3).

\section{Sequence analysis of isolated cDNA fragments.}

Fragments were isolated from the gels and reamplified, using nonlabeled primers that were identical to those employed for selective AFLP. Reamplification products were subjected to single-run, direct sequencing. A total of 71 fragments (69 induced and two repressed) were successfully sequenced and blasted against the The Arabidopsis Information Resource (TAIR) and GenBank databases (Altschul et al. 1997). Sequence similarity was found for 50 modulated cDNA fragments, while a group of 21 sequences showed homology to uncharacterized coding regions of the Arabidopsis genome. On the basis of sequence homology, differentially expressed cDNAs were grouped in seven categories of putative function (Fig. 3). The first group of sequences represents $14 \%$ of the differentially expressed genes (Fig. 4) and contains genes involved in signal transduction. These include various protein kinases, a protein phosphatase, a NAC-family protein (ATAF2) (Collinge and Boller 2001), a homologue of the ethylene-in- 


\begin{tabular}{|c|c|c|c|c|}
\hline n. & Homology & AGI number & $\begin{array}{c}\text { Blast N } \\
\text { Identities }\end{array}$ & CDNA-AFLP expression profile \\
\hline & Basic metabolism & & & \begin{tabular}{l}
\multicolumn{3}{c}{ SNP } \\
$10^{\circ}$ 1h 3 h
\end{tabular} \\
\hline 37 & alanine-glyoxylate aminotransferase & At2g13360 & $138 / 148$ & 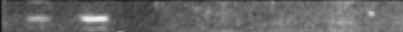 \\
\hline 38 & contains Plam profle PFo0016, exoblocin fam. & At1g67410 & $66 / 68$ & - \\
\hline 39 & E2, doquitin conkosting enzyme 10 (UeC10) & At5953330 & $116 / 116$ & - \\
\hline 40 & cytochrome p450 tamily & Al4g37370 & $196 / 205$ & 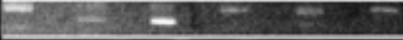 \\
\hline 41 & 40 S ribosomal protein $\$ 25$ & At2g21580 & $78 / 81$ & ㅇ․ 8 \\
\hline 42 & $60 S$ ribosomal protein L10, putative & At1g66580 & $63 / 63$ & 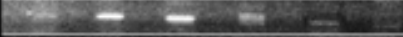 \\
\hline 43 & putative ribosomal-protein S6 kinase & At3g08720 & $109 / 110$ & 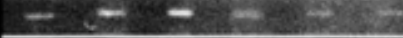 \\
\hline 44 & putative replication protein A1 & At2g24490 & $115 / 115$ & $3=-2=$ \\
\hline 45 & putative metalloproteinase & Al1g24140 & $139 / 141$ & - -2 \\
\hline 46 & putative auxin-regulated protein & At2g45210 & $109 / 112$ & $+2=$ \\
\hline 47 & putative aspartate aminotransferase & At2g22250 & $195 / 211$ & 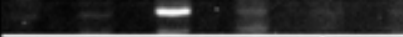 \\
\hline 48 & E2 utiquth ooriugating the onzyme, Ahuss & At3g57870 & $160 / 160$ & 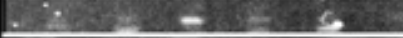 \\
\hline 49 & short chain alochel dehydrogenase the proe & A.4913180 & $223 / 223$ & - \\
\hline \multirow[t]{2}{*}{50} & 60 S ribosomal protein L34, putative & \multirow[t]{2}{*}{ At3g28900 } & \multirow[t]{2}{*}{$105 / 110$} & - \\
\hline & Unknown proteins & & & \\
\hline 51 & expressed protein & At2g05310 & $101 / 101$ & 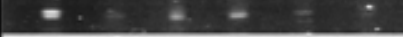 \\
\hline 52 & hypothetical protein & At2g30780 & $54 / 54$ & $-\quad-$ \\
\hline 53 & hypothetical protein & At1g54770 & $77 / 78$ & $-2-1=$ \\
\hline 54 & hypothetical protein & At2g05810 & $164 / 173$ & - \\
\hline 55 & putative protein & A.4g26240 & $233 / 233$ & - \\
\hline 56 & expressed protein & At1g80110 & $101 / 110$ & - \\
\hline 57 & putative protein & At5947540 & $155 / 155$ & 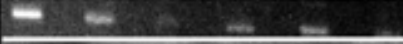 \\
\hline 58 & expressed protein & Al4g15790 & $228 / 230$ & $-2 \quad-1=$ \\
\hline 59 & unknown protein & At1g64650 & $125 / 128$ & $=$ \\
\hline 60 & putative protein & At5g42860 & $51 / 51$ & 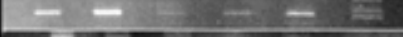 \\
\hline 61 & hypothetical protein & At1g57760 & $193 / 199$ & 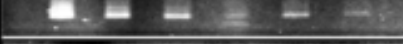 \\
\hline 62 & expressed protein & At1g69390 & $267 / 270$ & $2-$ \\
\hline 63 & unknown protein & At1g23030 & $116 / 116$ & $-2-5$ \\
\hline 64 & putative protein & At5g25360 & $85 / 85$ & 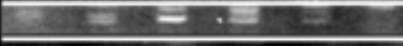 \\
\hline 65 & unknown protein & At1g64240 & $100 / 102$ & - \\
\hline 66 & expressed protein & At1g55480 & $69 / 69$ & 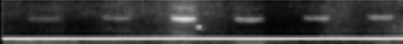 \\
\hline 67 & putative protein & Al4g11590 & $67 / 73$ & - \\
\hline 68 & unknown protein & At2g 25350 & $108 / 110$ & -2 \\
\hline 69 & hypothetical protein & At1g09950 & $77 / 80$ & $=$ \\
\hline 70 & expressed protein & At1g09070 & $280 / 282$ & $-\quad-\quad-$ \\
\hline 71 & putative protein & A:4g31670 & $168 / 168$ & $\operatorname{sen}^{2}-x^{2}=$ \\
\hline
\end{tabular}

Fig. 3. Continued

sensitive ein-3 gene, and a leucine-rich repeat (LRR) protein. The second group, enzymes and proteins involved in defense response and cell death, is not widely represented among the identified NO-modulated cDNAs $(5.6 \%)$ and includes the cysteine proteinase RD21, a $\beta$-1,3-glucanase-like protein and a cinnamate-4-hydroxylase. The third group (8.5\%) contains genes related to removal or production of toxic oxygen species, while the fourth $(9.9 \%)$ comprises genes involved in photosynthesis and energy transfer. Another two groups of differentially expressed sequences show homology to genes implicated in cellular trafficking $(2.8 \%)$ and in basic metabolic pathways $(29.6 \%)$. Previously uncharacterized genes also represent a large proportion $(29.6 \%)$ of the transcriptional changes detected. One differentially expressed cDNA, namely, the serine/threonine kinase At4g23240, is not represented by any known expressed sequence tag (EST) in the databases.

The same sequences were also clustered (Fig. 5) on the basis of their expression profiles (presence or absence of an evident change in band intensity at each time point), using the on-line cluster software EPCLUSTAL from the European Bioinformatic Institute. A significant proportion of the se-

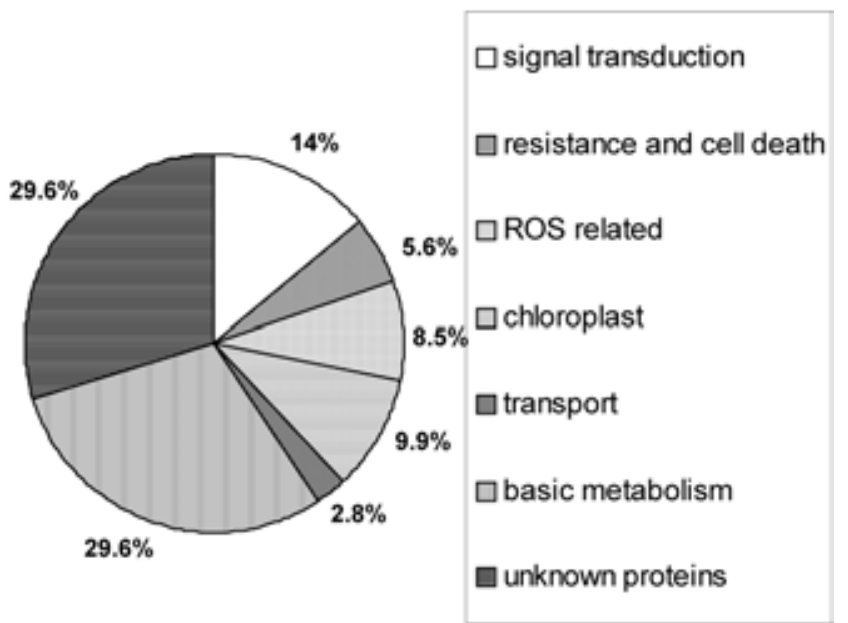

Fig. 4. Functional distribution of nitric oxide-modulated cDNAs, according to their homology to Arabidopsis genes or sequenced clones. 
quenced cDNAs showed a rapid transcriptional activation, as $38 \%$ increased within 10 min following treatment with SNP. This rapid accumulation was generally not long lasting, as only a small percentage of mRNAs still showed increased levels 1 or $3 \mathrm{~h}$ following treatment (5.6 and $1.4 \%$, respectively) (Fig. 5). Only $8.5 \%$ of genes showed an increase in

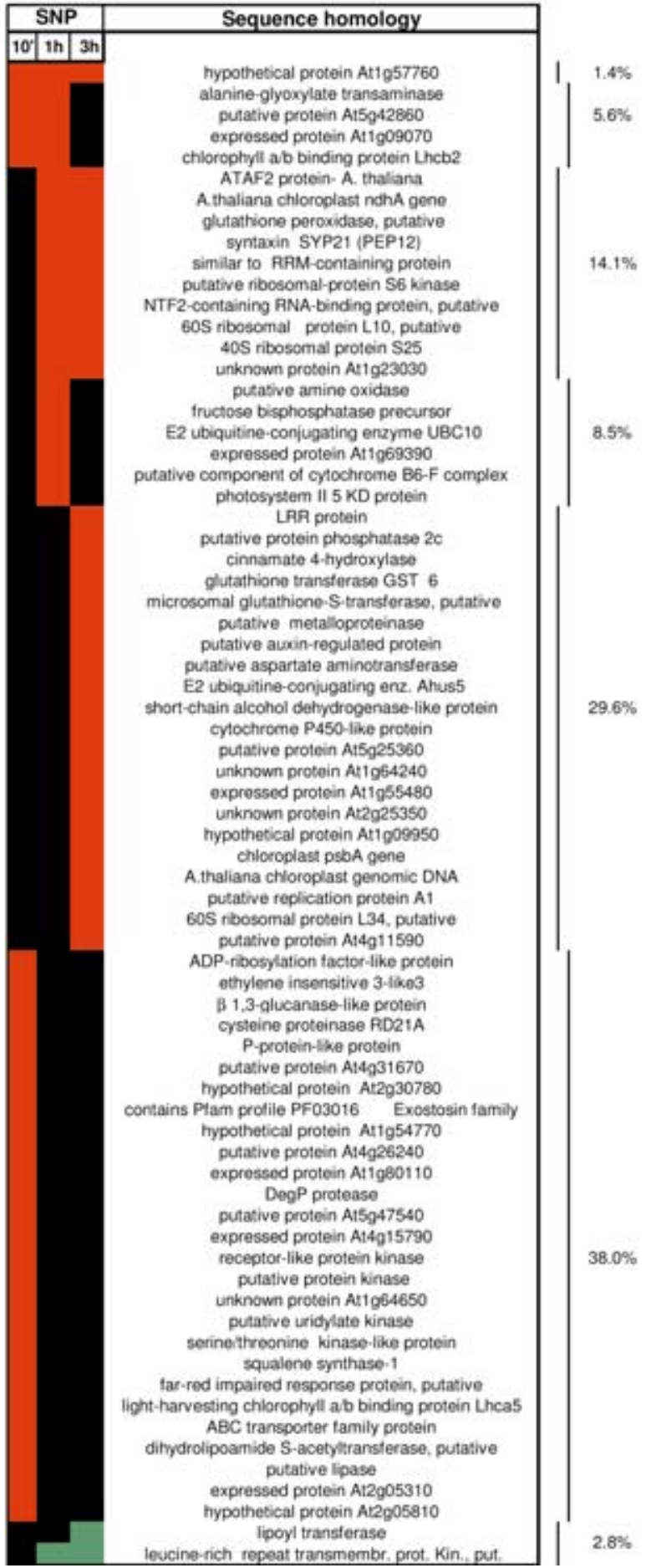

Fig. 5. Nitric oxide-modulated cDNAs, clustered on the basis of their transcript profile. The analysis was performed using the on-line software EPCLUSTAL, from the European Bioinformatic Institute. Data are referred to the presence or absence of an evident variation of transcription level at each timepoint in comparison with water infiltrated controls. Red indicates transcripts that showed increased expression, and green indicates transcripts that showed decreased expression. Black indicates timepoints when any specific cDNA did not show a relevant change in transcript level. transcript levels at $1 \mathrm{~h}$. For another $14.1 \%$, the increase was detected starting from $1 \mathrm{~h}$ and was maintained until the end of the experiment $(3 \mathrm{~h})$. For $29.6 \%$ of NO-modulated genes, transcript accumulation was detected $3 \mathrm{~h}$ after the treatment. Only two of the sequenced cDNAs showed repression in the transcription level $(2.8 \%)$.

\section{Validation of cDNA-AFLP expression profiles.}

The reproducibility of cDNA-AFLP has been extensively assessed (Bachem et al. 1996, 1998; Breyne et al. 2002, 2003; Durrant et al. 2000; Milioni et al. 2002; Qin et al. 2000; Van der Biezen et al. 2000). The technique adopted in our experiments (Breyne et al. 2002), although novel in the fact that it provides nonredundant detection of cDNA fragments, is not dissimilar from the rationale and general procedures of the classic technique (Bachem et al. 1996). The reproducibility of the technique was also extensively validated at our laboratory, when it was adopted. Moreover, we monitored by reverse transcription-polymerase chain reaction (RT-PCR) analysis the expression pattern of 10 differentially accumulated cDNAs (Fig. 6). Although, in some cases, the basal transcription level in water-infiltrated control samples appeared higher than that observed in cDNA-AFLP gels (Fig. 6B, F, and J), the expression patterns always mirrored the profiles observed in the cDNA-AFLP analysis. These genes were randomly selected from the different categories of modulated cDNAs.

\section{Expression of NO-modulated genes in disease-related conditions.}

To determine if any of the NO-modulated genes identified in the present work had been previously reported to be involved in specific disease-related conditions in plants, we monitored the presence and expression of these genes in four microarray sources: the Stanford Microarray Data Base and three published microarray analyses reporting transcriptional changes induced in Arabidopsis by different resistance-related treatments (Desikan et al. 2001; Schenk et al. 2000) or during systemic acquired resistance (Maleck et al. 2000). We also looked for information in a recent survey (Mahalingam et al. 2003) that reported a large collection of 1,058 cDNAs differentially expressed under eight different stress conditions, including pathogen infection.

The Stanford database reports transcriptional changes of about 11,000 EST, with a redundancy of about 25\% (Schaffer et al. 2001) under a range of many different biological treatments (180 at the time our comparison was made). From the list of the experiments performed, we selected 16 that may provide information about plant response to disease (Table 1). The experiments included viral, bacterial, and fungal infection, $\mathrm{H}_{2} \mathrm{O}_{2}$ or BTH (1,2,3-benzothiodiazole-7-carbothioic acid Smethyl ester) treatments, and analysis of mutants that are either compromised in fundamental steps of the disease response, such as $n a h G$ and nprl mutants, or overexpress resistance factors, such as edrl, cpr5, and cim7. A brief description of the experiments can be found in Table 2 (The Stanford Microarray Database provides more detailed information).

Of the 71 genes modulated by NO, only 37 were present in the Stanford microarray database (Table 1). For each sequence, the database reports expression levels in the different experiments as the average channel intensity ratio between treated and control samples. When examining in detail the expression of single genes in the different experiments reported, 31 of 37 NO-modulated genes were also found to be positively or negatively affected in one or more experiments related to disease and resistance. The EST most frequently affected in such experiments corresponded to the receptorlike protein kinase At4g04570 (upregulated in five experiments and down-regulated in two). Other EST were also affected by several treatments, namely the fruc- 
tose 1-6 bisphosphate precursor, the chloroplast psbA gene, and the short-chain alcohol dehydrogenase.

Moreover, 15 of the 16 selected experiments determined transcriptional changes of several genes identified as NOmodulated in our survey. The experiments that affect the higher number of NO-modulated genes are bacterial infection of wild-type Arabidopsis plants (ID number 4940), $\mathrm{H}_{2} \mathrm{O}_{2}$ treatment (ID number 9371), and infection of $\operatorname{cim} 7$ (ID number 11770) and cpr5 (ID number 11775) mutants with a powdery mildew fungus.

We also searched for additional information about the possible function of these NO-modulated genes by comparing their expression in the microarray analysis by Schenk and associates (2000). The expression pattern of 2,375 selected genes following infection of $A$. thaliana with Alternaria brassicicola or following treatment with the defense-related signal molecules SA, methyl-jasmonate (MeJA), or ethylene is detailed in Table 3. Only eight genes among those found to be modulated by NO are present in the array, all of which are also affected by one or more treatments, mostly by SA and MeJa.

The microarray surveys presented by Maleck and associates (2000) and Desikan and associates (2001) were also considered. Maleck and associates monitored expression changes of about 7,000 nonredundant EST of A. thaliana (25 to $30 \%$ of the transcriptome) under 14 different SAR-inducing or -repressing conditions. Among the 413 EST that were affected by SAR-related treatments, only two correspond to genes that we identified as NO-induced, namely an expressed protein (At1g09070) and a chlorophyll a/b binding protein
(At2g05070). As the complete list of genes reported in the array is not available, we cannot determine whether the other 69 NO-modulated genes were not affected by SAR or whether they were not represented in the microarray.

Desikan and associates (2001) identified 175 nonredundant EST that are regulated by $\mathrm{H}_{2} \mathrm{O}_{2}$. In this case, we could find information on only four NO-induced genes, three of which were also induced by $\mathrm{H}_{2} \mathrm{O}_{2}$ (ATAF2 protein, GST6, and the shortchain alcohol dehydrogenase) while the fourth (cysteine proteinase $\mathrm{RD} 21 \mathrm{~A}$ ) was repressed by $\mathrm{H}_{2} \mathrm{O}_{2}$.

Finally, upon examination of the results obtained by Mahalingam and associates (2003), we found that 12 NOmodulated genes are also expressed in other stress conditions. Microarray data from the same paper indicates that four NOmodulated genes (glutathione transferase GST 6, E2 ubiquitinconjugating-like enzyme Ahus5, the expressed proteins At1g69390, and At1g09070) are induced in Arabidopsis 5 days postinoculation upon infection with virulent Peronospora parasitica and that the same genes (except Ahus5) are also induced by $1 \mathrm{~h}$ of ozone exposure.

\section{Bio-informatic functional survey}

on NO-modulated genes coding for unknown proteins.

About $30 \%$ of all NO-affected transcripts showed homology to sequences coding for presently unclassified proteins. The $A$. thaliana database at MIPS (Munich Information Center for Protein Sequences) has been consulted to obtain further information on putative protein function. "Automatically derived functional categories" of all 21 sequences are presented in Table 4. The first

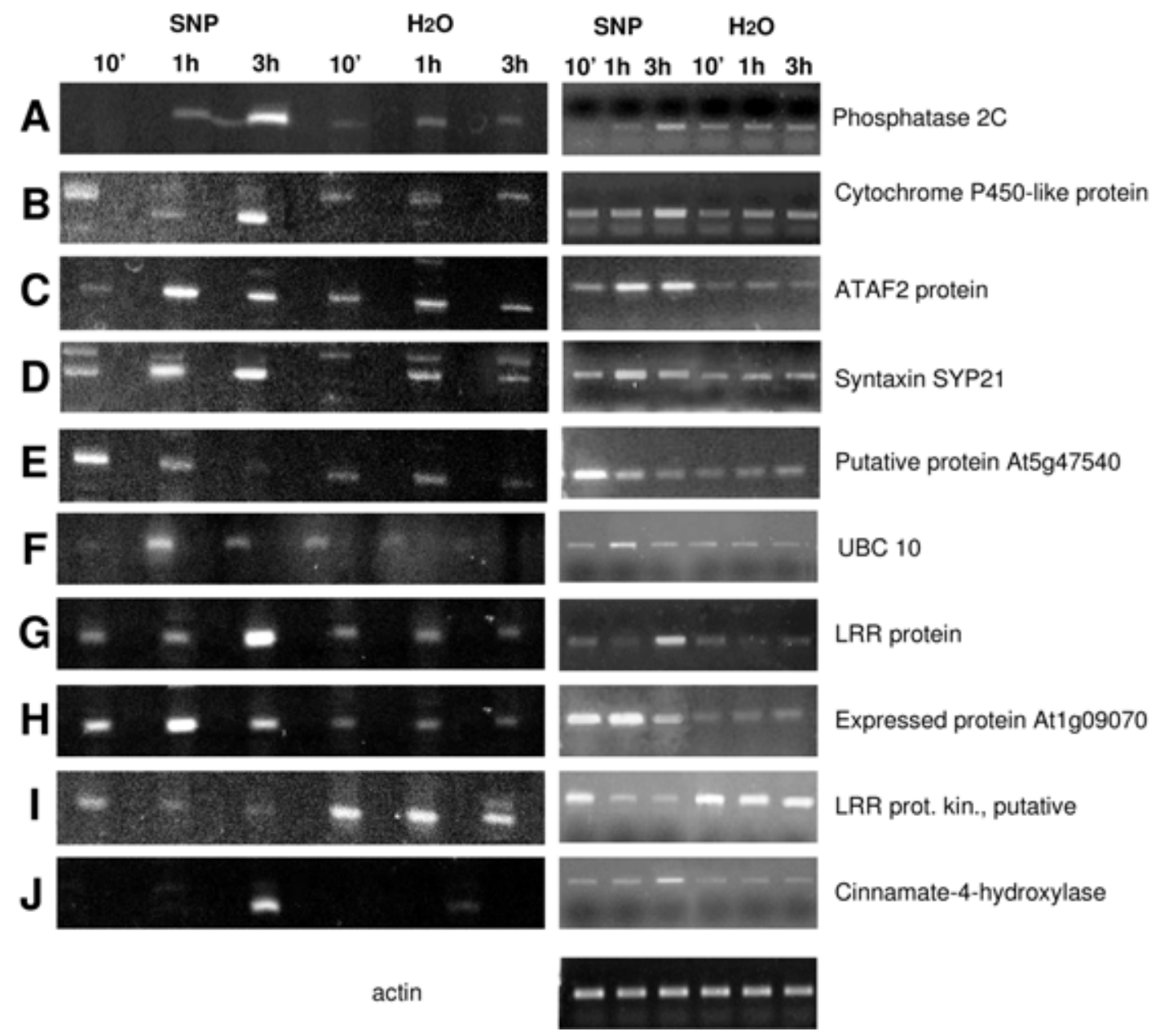

Fig. 6. Reverse transcription-polymerase chain reaction (RT-PCR) expression analysis of 10 selected nitric oxide-induced genes, in comparison with the expression profiles observed by cDNA-amplification fragment length polymorphism. Actin expression profile in the RT-PCR experiments is reported as a control. 
Table 1. Expression analysis of 37 nitric oxide (NO)-modulated genes in 16 defense-related experiments, as obtained from the Stanford microarray database. For each expressed sequence tag (EST), the table reports expression levels in the different experiments as the average channel intensity ratio between treated and control samples. Ratios in bold indicate an intensity ratio of 1.5 or higher, whereas shading indicates an intensity ratio of 0.5 or less.

\begin{tabular}{|c|c|c|c|c|c|c|c|c|c|c|c|c|c|c|c|c|c|c|}
\hline \multirow{3}{*}{$\begin{array}{c}\text { NO-modulated } \\
\text { genes }\end{array}$} & \multirow{3}{*}{$\begin{array}{c}\text { AGI } \\
\text { number }\end{array}$} & \begin{tabular}{|c|}
$\begin{array}{c}\text { Stanford } \\
\text { microarray } \\
\text { experiment } \\
\text { ID }\end{array}$ \\
\end{tabular} & 4940 & 7342 & 13813 & 9754 & 11762 & 9371 & 11763 & 10027 & 11764 & 11770 & 11766 & 11775 & 11767 & 11776 & 7349 & 11780 \\
\hline & & $\begin{array}{l}\text { Experiment } \\
\text { description }\end{array}$ & 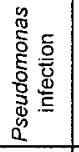 & 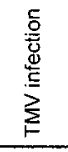 & 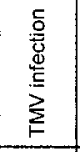 & 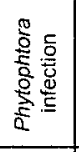 & 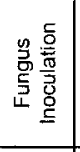 & 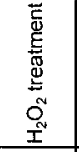 & 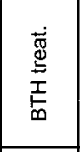 & $\frac{\sum}{\frac{5}{3}}$ & 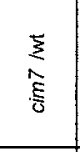 & 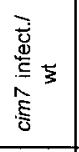 & $\begin{array}{l}\xi \\
3 \\
8 \\
8\end{array}$ & 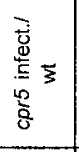 & $\begin{array}{l}\frac{5}{3} \\
\frac{5}{2}\end{array}$ & 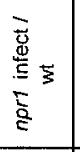 & 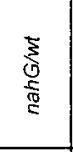 & 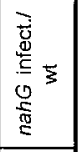 \\
\hline & & EST & & & & & & & & & & & & & & & & \\
\hline $\begin{array}{c}\begin{array}{c}\text { receptor-like } \\
\text { protein kinase }\end{array} \\
\end{array}$ & Al4g 04570 & $\mathrm{~T} 43643$ & .872 & .949 & & .864 & 140 & 1.278 & \begin{tabular}{|l|l|}
4.146 \\
\end{tabular} & 1.008 & .906 & 2.826 & 2.041 & 3.983 & .811 & 1.671 & 295 & .681 \\
\hline $\begin{array}{c}\text { ADP-ribosylation factor-like } \\
\text { protein }\end{array}$ & A15g67560 & AA651549 & 1.326 & 1.182 & .975 & 1.036 & & 1.869 & 1.12 & 1.944 & 1.29 & .911 & .893 & .775 & & 1.323 & 1.242 & 1.294 \\
\hline ATAF2 protein & At5g08790 & H37631 & 334 & 1.218 & 1.788 & .914 & 1.114 & 1.869 & 1.158 & .943 & & 1.711 & & 1.597 & 1.25 & 1.11 & 629 & .935 \\
\hline LRR protein & At5g21090 & 234187 & & 1.365 & 1.469 & .857 & .889 & 1.34 & 1.12 & 1.696 & .842 & 1.359 & .923 & 1.932 & 84 & .639 & 1.401 & .809 \\
\hline $\begin{array}{l}\text { putative protein } \\
\text { phosphatase } 2 \mathrm{C}\end{array}$ & At2g20630 & N37783 & 1.175 & 1.277 & 1.034 & 1.04 & .942 & .824 & 1.179 & .789 & .765 & .781 & .894 & 1.031 & .725 & 1.245 & .581 & .972 \\
\hline cinnamate-4-hydroxylase & AL2g30490 & T44874 & & .698 & .915 & & & 1.815 & & .94 & .68 & 488 & .705 & & .623 & 1.131 & 1.281 & .974 \\
\hline putative amine oxidase & AL2943020 & N65854 & .664 & 1.102 & & & 1.024 & & & .741 & & 474 & 1.264 & 1.04 & .991 & 1.177 & - & .963 \\
\hline $\begin{array}{c}\text { fructose- } 1,6 \\
\text { bisphosphatase precursor }\end{array}$ & At3g54050 & Al100692 & 2.104 & 1.452 & & 1.157 & .699 & .689 & $49+$ & 456 & .815 & 328 & 486 & 379 & .879 & 1.103 & .969 & .758 \\
\hline $\begin{array}{l}\mathrm{NADH} \text { plastoquinone } \\
\text { oxidoreductase }\end{array}$ & X98298 & AA042536 & 1.077 & 1.02 & .678 & .793 & & 1.116 & .617 & .693 & & & .773 & .615 & .821 & .94 & - & .672 \\
\hline $\begin{array}{l}\text { glutathione peroxidase, } \\
\text { putative }\end{array}$ & At4g11600 & T20445 & 1.244 & 1.463 & 201 & & 1.101 & 1.605 & 2.134 & & 1.077 & .814 & 1.048 & .971 & 1.126 & 1.506 & 1.316 & 1.362 \\
\hline $\begin{array}{l}\text { glutathione-S-transferase } \\
\text { GST6 }\end{array}$ & A12g47730 & H36739 & 1.41 & 1.187 & 1.118 & .783 & 1.113 & 2.453 & .8 & 2.044 & 1.049 & 1.391 & & & 1.168 & 1.059 & 1.704 & 1.192 \\
\hline $\begin{array}{c}\text { microsomal glutathione-s- } \\
\text { transferase, putative }\end{array}$ & At1g65820 & AA712909 & .735 & & 1.19 & 1.629 & 1.204 & .519 & 1.835 & .715 & & 1.289 & 1.066 & 1.196 & 1.242 & 1.498 & .562 & 1.335 \\
\hline $\begin{array}{c}\text { far-red impaired response } \\
\text { proteln, putative }\end{array}$ & At3g22170 & T20465 & .756 & .929 & & 1.089 & 1.021 & .977 & & 1.25 & 1.025 & 1.13 & 1.413 & & 1.172 & 1.049 & 1.202 & .785 \\
\hline $\begin{array}{c}\text { light-harvesting chlorophyit } \\
\text { a/b binding protein }\end{array}$ & At1g 95474 & H36329 & 1.556 & .977 & .822 & .915 & .955 & 1.078 & .909 & 1.238 & & .622 & .628 & 412 & 1.035 & .968 & - & \\
\hline $\begin{array}{c}\text { light-harvesting chlorophyift } \\
\text { a/b binding protein }\end{array}$ & At2g05070 & T43199 & 2.085 & 1.686 & 499 & & .836 & 1.199 & .665 & .788 & & 485 & .639 & .93 & .533 & 1.628 & 1.189 & 1.111 \\
\hline $\begin{array}{c}\text { putative component of } \\
\text { cytoctrome } 86-F \text { complex }\end{array}$ & At4903280 & T04392 & 2.115 & 1.301 & .62 & .982 & .826 & .649 & & .52 & 1.012 & 429 & .677 & & .695 & & 1.037 & .942 \\
\hline 5KD PS II protein & N38665 & N37634 & 2.024 & 1.126 & .517 & .725 & .83 & & $45 \div$ & .667 & .928 & .542 & & .536 & .808 & .885 & .713 & 893 \\
\hline chloroplast psbA gene & NC000932 & N96425 & .583 & 1.446 & 1.931 & .901 & 1.102 & & 817 & .522 & 435 & 18 & 19 & 153 & .523 & 081 & 1.456 & 1.276 \\
\hline P.Protein-like prote in & At4933010 & H37261 & 4.744 & .796 & & 1.588 & .83 & & 1.075 & 1.042 & & .757 & & & .837 & 1.09 & .793 & 846 \\
\hline $\begin{array}{c}\begin{array}{c}\text { similar to } \\
\text { RRM-containing } \\
\text { protein }\end{array} \\
\end{array}$ & At1g 33470 & AA404956 & .939 & .896 & & .573 & 1.117 & 1.438 & .948 & 1.798 & .955 & 1.661 & 1.215 & & 1.308 & & 1.698 & 1.176 \\
\hline $\begin{array}{l}\text { NTF2-containing RNA- } \\
\text { binding protein, putative } \\
\end{array}$ & At5943960 & T43735 & 1.779 & 1.088 & .882 & 1.427 & .85 & .86 & \begin{tabular}{|l|l|}
1.199 \\
\end{tabular} & .716 & .857 & .664 & .744 & .788 & .525 & .968 & - & .727 \\
\hline putative lipase & At1g10740 & $T 76725$ & 1.003 & 1.033 & .878 & .806 & 1.103 & & .856 & .955 & 1.002 & 1.638 & .986 & 1.406 & 1.167 & .862 & - & 1.127 \\
\hline DegP protease & At3g03380 & AA042442 & 1.113 & 1.04 & .743 & 1.943 & 1.019 & .832 & & & 1.632 & & .984 & .628 & 1.123 & 1.132 & 1.664 & 1.15 \\
\hline $\begin{array}{l}\text { alanine-glyoxylate } \\
\text { aminotransferase }\end{array}$ & At2g13360 & H36019 & 1.209 & 1.549 & .901 & & 1.029 & .907 & 1.372 & & 1.41 & .97 & & .977 & 1.315 & 1.546 & .967 & 1.014 \\
\hline $\begin{array}{l}\text { ubiqut. conjugating } \\
\text { enzyme UBC10 }\end{array}$ & At5953330 & †20629 & 1.001 & 1.416 & 1.149 & 1.637 & 1.045 & .728 & 1.229 & .749 & 1.252 & .93 & 1.064 & .98 & 1.128 & 1.443 & .627 & 1.272 \\
\hline $\begin{array}{c}60 S \text { ribosomal protein } \\
\text { L10, putative }\end{array}$ & At1g 66580 & AA041180 & .709 & 1.489 & 1.14 & & .721 & 1.504 & 1.289 & .893 & .746 & 402 & .561 & .755 & .559 & 1.302 & 1.411 & 692 \\
\hline $\begin{array}{c}\text { putative auxin-regulated } \\
\text { protein }\end{array}$ & At2 245210 & T41970 & .911 & 1.038 & .605 & 1.161 & 1.075 & .723 & .787 & 1.003 & 1.164 & 1.108 & & & 1.181 & 1.683 & 1.410 & \\
\hline $\begin{array}{l}\text { putative aspartate } \\
\text { aminotransferase }\end{array}$ & At2g22250 & T21377 & 1.697 & 1.128 & .659 & 1.262 & 1.108 & .849 & 1.125 & .572 & 1.079 & 1.111 & 1.254 & 1.364 & & 1.215 & - & 1.072 \\
\hline $\begin{array}{c}\text { short-chain alcohol } \\
\text { dehydrogenase-ilike protein }\end{array}$ & At 4913180 & N37618 & 1.079 & 1.003 & & .579 & 1.33 & 2.287 & 1.155 & 2.733 & .925 & 2.13 & 1.307 & 2.243 & 1.536 & .756 & 1.785 & 1.218 \\
\hline $\begin{array}{l}\text { 60S ribosomal protein } \\
\text { L34, putative }\end{array}$ & At3g28900 & AA597732 & 1.068 & 1.082 & .878 & 1.015 & 1.023 & .876 & 1.226 & 1.217 & 1.13 & .971 & & 1.083 & & 1.312 & .988 & 869 \\
\hline expressed protein & AL2905310 & AA605343 & 1.664 & & & .647 & 1.042 & 1.697 & .748 & 2.567 & 1.006 & 1.386 & & 1.14 & 1.163 & .891 & 1.607 & 1.17 \\
\hline hypothetical protein & At1g54770 & AA404747 & 1.083 & .893 & 1.267 & 1.312 & .911 & & .879 & 1.074 & 1.019 & .881 & & .89 & & & 676 & .858 \\
\hline purative protein & At5g 47540 & AA728481 & .618 & 1.391 & & 1.16 & .772 & .851 & .941 & .761 & .751 & 345 & 492 & 442 & .625 & & .800 & 877 \\
\hline unkrown protein & At1964650 & AA605519 & 1.073 & & & .864 & 1.084 & .658 & .853 & 1.222 & & 1.323 & & 1.223 & 1.159 & .913 & - & .996 \\
\hline expressed protein & At1g69390 & T13677 & 1.462 & 1.747 & .904 & & 1.022 & & 1.121 & & 1.16 & .833 & .995 & .698 & .907 & 1.47 & - & .858 \\
\hline unknown protein & At1g64240 & AA597840 & . 985 & & & 2.083 & 1.115 & & 1.581 & .888 & 1.31 & 1.317 & 1.233 & 1.257 & & 1.537 & 1.336 & - \\
\hline expressed protein & At1g09070 & $T 21700$ & 1.573 & 1.002 & 2.331 & 1.18 & 1.133 & .851 & .918 & 1.027 & .7 & .868 & & 1.41 & .735 & 1.274 & 1.423 & 81 \\
\hline
\end{tabular}


column reports the relative AGI number, while the second and third columns report the blast match for each protein and the Evalue. The last two columns indicate the presence or absence of a signal for targeting of the protein to specific cellular compartments and the presence in the sequence of putative transmembrane domains. Interestingly, some of the blast matches obtained correspond to proteins that might be involved in signal transduction, namely a transcription factor, OBF4 from $A$. thaliana, a hypothetical calcium binding protein, along with a protease and a phosphatase.

\section{DISCUSSION}

As derived from in silico analysis of A. thaliana full-length cDNAs, about $65 \%$ of all transcripts are cut by the two restriction enzymes used (Bst YI and $M s e \mathrm{I})$ and are of the proper size for visualization on polyacrylamide gels and can, therefore, be detected by this technique (Breyne et al. 2002). Choosing $B s t \mathrm{YI}$ as the rare cutter yields fragments with an average distance from the polyA $\mathrm{A}^{+}$tail of $500 \mathrm{bp}$ (Breyne et al. 2002). The procedure adopted, with 32 primer combinations, allowed us to survey the expression level of about 2,500 different transcripts and to detect differential expression for 120 cDNA fragments. This represents about $5 \%$ of the examined transcripts, which suggests that a high proportion of the Arabidopsis transcriptome is influ- enced by NO treatment. Following purification of excised and reamplified bands, 71 cDNA fragments could be successfully sequenced, while the other fragments could not be sequenced due to the low efficiency of the approach adopted. Single-run, direct sequencing without cloning allows a more rapid survey of band identity, although with a higher percentage of sequencing failures with respect to cloned PCR products.

Beside the well-established, fundamental role of NO in the activation of an HR (Durner et al. 1998; Delledonne et al. 2003), the analysis of gene expression profiles in NO-treated Arabidopsis leaves shows that it can influence the transcriptional activity of a wide set of genes, most of which do not appear to be specifically involved in the activation of resistance or cell death. These findings are in agreement with the concept that plant metabolic pathways leading to disease resistance are largely interconnected with several aspects of primary and secondary plant metabolism (Batz et al. 1998; Scheideler et al. 2002) and that NO can act through different mechanisms on a wide set of genes and metabolic processes (Nürnberger and Scheel 2001).

Previous wide surveys on gene expression also reported a large increase in transcriptional activity during stress or disease-related conditions (Cheong et al. 2002; Desikan et al. 2001; Durrant et al. 2000; Mahalingam et al. 2003; Maleck et al. 2000; Seki et al. 2002) and a shift from housekeeping to

Table 2. Description of experiments from the Stanford microarray database and replicate numbers

\begin{tabular}{|c|c|c|c|}
\hline ID number & Name & Description & Replicates \\
\hline 4940 & $\begin{array}{l}\text { Bacterial pathogen } \\
\text { inoculation }\end{array}$ & $\begin{array}{l}\text { Analysis of the Arabidopsis response to a Pseudomonas syringae pv. tomato DC } 3000 \text { virulence- } \\
\text { compromised mutant, to identify Arabidopsis genes regulated by CEL-encoded virulence proteins } \\
\text { secreted via the type III secretion system. }\end{array}$ & 2 \\
\hline 7342 & Disease response 1 & $\begin{array}{l}\text { Identification of plant genes that are differentially regulated during Tobacco mosaic virus infection } \\
\text { in susceptible Arabidopsis (ecotype Shahdara), } 3 \text { days after inoculation. }\end{array}$ & 2 \\
\hline 13813 & Infection response 1 & $\begin{array}{l}\text { Identification of plant genes that are differentially regulated during systemic Tobacco mosaic virus } \\
\text { infection in susceptible Arabidopsis (ecotype Shahdara) leaves, } 14 \text { days after inoculation. }\end{array}$ & 2 \\
\hline 9754 & $\begin{array}{l}\text { Pathogen response } \\
\text { 2-reverse }\end{array}$ & $\begin{array}{l}\text { Identification of novel defense pathways associated with nonhost resistance of Arabidopsis to the } \\
\text { oomycete Phytophthora infestans. Experiment performed one day after inoculation. }\end{array}$ & 2 \\
\hline 11762 & A infected & $\begin{array}{l}\text { Identification of plant genes that are differentially regulated during powdery mildew infection of } \\
\text { Arabidopsis Columbia leaves, in comparison with healthy leaves, } 48 \mathrm{~h} \text { after inoculation. }\end{array}$ & 1 \\
\hline 9371 & Cell death 1 & $\begin{array}{l}\text { Identification of hydrogen peroxide-regulated genes expressed during programmed cell death in } \\
\text { Arabidopsis suspension cultures. }\end{array}$ & 2 \\
\hline 11763 & B-BTH & Comparison of $0.3 \mathrm{mM}$ BTH-treated Columbia plants with untreated plants. & 1 \\
\hline 10027 & edrl mutant 1 & Comparison of $e d r 1$ mutants with Columbia wild-type plants. & 1 \\
\hline 11764 & C-cim7 & Comparison of $\operatorname{cim} 7$ mutants with Columbia wild-type plants & 1 \\
\hline 11770 & E-cim 7 infected & $\begin{array}{l}\text { Analysis of } \operatorname{cim} 7 \text { plants infected with powdery mildew in comparison with Columbia wild type, } 48 \mathrm{~h} \\
\text { after inoculation. }\end{array}$ & 1 \\
\hline 11766 & D-cpr 5 & Comparison of $\operatorname{cpr} 5$ mutants with Columbia wild-type plants & 1 \\
\hline 11775 & F-cpr 5 infected & $\begin{array}{l}\text { Analysis of } \operatorname{cpr} 5 \text { plants infected with powdery mildew in comparison with Columbia wild type, } 48 \mathrm{~h} \\
\text { after inoculation. }\end{array}$ & 1 \\
\hline 11767 & G-nprl & Comparison of $n p r l$ mutants with Columbia wild-type plants. & 1 \\
\hline 11776 & I-nprl infected & $\begin{array}{l}\text { Analysis of } n p r l \text { plants infected with powdery mildew in comparison with Columbia wild type, } 48 \mathrm{~h} \\
\text { after inoculation. }\end{array}$ & 1 \\
\hline 7349 & Salicylic acid 2 & $\begin{array}{l}\text { Comparison of nahG plants with wild-type Columbia. Identification of genes and/or pathways } \\
\text { involved in salicylic acid-dependent coupled regulation of cell growth and cell death. }\end{array}$ & 2 \\
\hline 11780 & $\mathrm{~J}-N a h G$ infected & $\begin{array}{l}\text { Analysis of } n a h G \text { plants infected with powdery mildew in comparison with Columbia wild type, } 48 \mathrm{~h} \\
\text { after inoculation. }\end{array}$ & 1 \\
\hline
\end{tabular}

Table 3. Expression analysis ratios of eight nitric oxide-modulated genes in disease-related experiments ${ }^{\mathrm{a}}$

\begin{tabular}{|c|c|c|c|c|c|}
\hline Function & Accession number & Alternaria brassicicola & Salicylic acid & Methyl jasmonate & Ethylene \\
\hline LRR protein & Z34187 & 2.6917 & 1.1671 & 1.7721 & 1.493 \\
\hline ATAF2 protein & H37631 & 1.31822 & 0 & $\mathbf{3 . 0 3 9 5}$ & 1.8005 \\
\hline Beta-1,3-endoglucanase & R90193 & -1.1064 & -2.7245 & -1.5172 & 1.542 \\
\hline Chlorophyll $\mathrm{a} / \mathrm{b}$-binding protein & R90262 & 1.0194 & 7.25163 & 1.4894 & -1.9121 \\
\hline Cysteine proteinase RD21A & T22938 & 1.516 & 1.867 & 3.1416 & 1.5603 \\
\hline Fructose-1,6-bisphosphatase & T21336 & 1.4825 & 2.3413 & -3.6908 & 0 \\
\hline Ubiquitin-conjugating enzyme & T20629 & 2.57 & 2.1358 & 2.3148 & 2.1445 \\
\hline Photosystem II 5 KD protein & N37634 & 1.9 & 3.5014 & -1.2298 & -1.1824 \\
\hline
\end{tabular}

${ }^{a}$ As obtained from the microarray analysis published by Schenk and associates (2000). Values in bold indicate changes in expression level, according to the threshold established by the authors ( \pm 2.0 -fold). 
defense metabolism in plants responding to pathogens (Batz et al. 1998; Scheideler et al. 2002), with various degrees of overlap in response to different stimuli.

Homologies for all sequenced NO-modulated cDNA fragments were divided in functional categories and clustered on the basis of their expression profiles (Figs. 3 and 5). An important set of NO-modulated transcripts corresponds to proteins that might have a regulatory role as transcription factors or as components of signal transduction cascades (Fig. 3). Among these are: i) five kinases, four of which show a rapid increase at 10 min after SNP infiltration, with one not being represented by any EST; NO is known to affect the expression and activity of disease-related kinases (Kumar and Klessig 2000), therefore these newly identified NO-modulated kinases might also mediate different NO actions in plants; ii) a homologue to ein3, a gene involved in ethylene perception and transduction (Chang and Stadler 2001); NO is known to influence several ethylenedependent processes in the plant life cycle (Leshem et al. 1998); iii) ATAF2, a protein belonging to the NAC domain protein family, found so far only in plants and involved in cell damage and death during both infection and wounding (Collinge and Boller 2001); iv) a LRR protein; LRR proteins form a large family of proteins with fundamental functions as receptors, including perception of pathogens by plants (Jones and Jones 1997); the same transcript was also induced by Alternaria brassicicola but not by SA, MeJA, or ethylene in Arabidopsis plants (Schenk et al. 2000; Table 3), nor by $\mathrm{H}_{2} \mathrm{O}_{2}$ (Desikan et al. 2001) (Table 1). Thus, NO appears to be the only molecule involved in the defense response identified to date to affect the transcription of this LRR gene.

Differentially induced cDNAs corresponding to genes related to defense or cell death represent a small percentage of NO-induced transcriptional changes, at least within the first three hours; $\beta-1,3$ glucanase induction by NO was previously reported (Beligni et al. 1997). The early induction we observed indicates that NO can activate $\beta-1,3$ glucanase transcript accumulation long before the onset of cell death. Other PR proteins, namely PR-1, have been shown to be transcriptionally activated by NO (Durner et al. 1998). Another enzyme involved in defense whose transcription is strongly activated by $\mathrm{NO}$ is cinammate-4-hydroxylase $(\mathrm{C} 4 \mathrm{H})$, a key enzyme in the phenylpropanoid pathway. This pathway starts from PAL, which was also shown to be induced by NO in plants (Durner et al. 1998), leading to the synthesis of phenolic compounds related to defense and to the production of flavonoids via chalcone synthase (CHS), whose transcription is also modulated by NO (Delledonne et al. 1998). The finding that $\mathrm{C} 4 \mathrm{H}$ transcription increases following SNP infiltration further supports the notion that defense responses related to the phenylpropanoid pathway are induced by NO in plants. A gene encoding the stressrelated cysteine protease RD21A (Koizumi et al. 1993) was induced by NO at $10 \mathrm{~min}$ after treatment. Caspases, cysteine proteases specific for target sites containing aspartate residues, are of crucial importance in mediating apoptosis in animals (Cryns and Yuan 1998). A caspaselike activity is detectable in hypersensitively reacting cells (del Pozo and Lam 1998) and following treatment with NO donors (Clarke et al. 2000). Specific caspase inhibitors also suppress HR and NO-induced cell death. Recently, a set of cysteine proteases has been implicated as mediators of pathogen-induced cell death in plants (Lam and del Pozo 2000; Solomon et al. 1999). The strong induction of RD21A following PCD-related treatments in vitro indicates a likely involvement in cell death activation in plants (Swidzinski et al. 2002).

Another set of genes differentially expressed in SNP-treated Arabidopsis leaves is related to ROS generation and removal. The activation of genes corresponding to protective enzymes, such as glutathione-S-transferase and glutathione peroxidase, is consistent with known events occurring during the cell death process induced by $\mathrm{NO}$ and ROS or by avirulent pathogens (Lamb and Dixon 1997; Van Camp et al. 1998). A cDNA corresponding to fructose 1-6 bisphosphatase (FBF), one of the major targets of the thioredoxin system, also showed an increased expression after treatment with SNP. A FBF gene was reported to be differentially expressed in SA-treated Arabidopsis leaves (Schenk et al. 2000) (Table 3) and in apoptosis-resistant lymphoma $\mathrm{B}$ cells in response to ionizing radiation (Voehringer et al. 2000). Its expression can lead to an increase in total cellular glutathione (Voehringer et al. 2000), and it is, thus, assumed to participate in the antioxidant machinery during cell death.

A pool of genes whose transcription is influenced by $\mathrm{NO}$ is involved in the photosynthetic process, both in light perception and in energy transfer (Fig. 3). Their activation is consistent with known or hypothesized effects of $\mathrm{NO}$ on mitochondrion and chloroplast activity (Saviani et al. 2002; Takahashi and Yamasaki 2002). Interconnections between the light transduc-

Table 4. Automatically derived functional categories of all 21 sequences related to unknown proteins identified in this study ${ }^{\mathrm{a}}$

\begin{tabular}{|c|c|c|c|c|}
\hline AGI number & Blast match & E-value & Target signal & Trans-membrane domain \\
\hline At $2 \mathrm{~g} 05310$ & Putative protein & $5 e-51$ & $\mathrm{CHL}$ & yes \\
\hline At $2 \mathrm{~g} 30780$ & Putative protein & $9 \mathrm{e}-71$ & MIT & no \\
\hline At1g54770 & Similarity to human acidic $82-\mathrm{kDa}$ protein & $5 e-40$ & - & no \\
\hline At $2 \mathrm{~g} 05810$ & AAF49109.1 karyopherin-alpha1 gene product [Drosophila melanogaster] & $1 e-68$ & - & yes \\
\hline At4g26240 & Putative protein & - & - & no \\
\hline At1g80110 & Lectine like protein & $3 e-58$ & - & no \\
\hline At5g47540 & Mouse hypotetical calcium binding protein -Drosophyla Mo25 gene & $1 \mathrm{e}-134$ & MIT & no \\
\hline At4g15790 & Unclassified protein & - & $\mathrm{CHL}$ & no \\
\hline At1g64650 & Unclassified protein & 0 & SEC & yes \\
\hline At5g42860 & Unclassified protein & - & CHL & yes \\
\hline At1g57760 & Putative protein & $7 e-29$ & SEC & yes \\
\hline At1g69390 & Unclassified protein & - & $\mathrm{CHL}$ & yes \\
\hline At1g23030 & Arm repeat containing protein homolog A. thaliana & $1 \mathrm{e}-70$ & - & no \\
\hline At5g25360 & Unclassified protein & $1 e-73$ & - & no \\
\hline At1g64240 & putative protein (non-LTR retroelements) & 0.00 & - & yes \\
\hline At1g55480 & protein-tyrosine-phosphatase, nonreceptor type 13 , mouse & 0.11 & CHL & no \\
\hline At4g 11590 & putative protein A. thaliana & $1 \mathrm{e}-114$ & - & no \\
\hline At $2 \mathrm{~g} 25350$ & RRP40 protein involved in ribosomal RNA processing $S$. cerevisiae & $4 e-29$ & - & yes \\
\hline At1g09950 & Transcription factor $\mathrm{OBF} 4$ A. thaliana & $2 \mathrm{e}-59$ & SEC & no \\
\hline At1g09070 & Unclassified protein & - & - & yes \\
\hline At4g31670 & KIAA1063 protein (proteolytic degradation) H. sapiens & $1 \mathrm{e}-95$ & SEC & yes \\
\hline
\end{tabular}

${ }^{a}$ Data are derived from the Munich Information Center for Protein Sequences Arabidopsis thaliana database. 
tion apparatus and components of the resistance response to pathogens have already been shown (Genoud et al. 1998). Moreover, a synergistic action of phytochrome signaling in SA induction of PR-1a gene expression has recently been reported (Genoud et al. 2002).

Other cDNAs isolated in response to NO treatment correspond to genes involved in cellular trafficking, which can also be involved in the stress response; syntaxin, in particular, has been implicated in the machinery regulating apoptosis in animals (Roperch et al. 1999). However, about $30 \%$ of the identified cDNAs are not easily allocated in any of the preceding categories and are related to basic cellular functions (Fig. 4). Among these genes, we found that NO also triggers the activation of two ubiquitin conjugating enzymes, namely UBC 10 and Ahus5. Although they are considered housekeeping genes, connections between ubiquitylation and the HR or programmed cell death have already been reported (Bachmair et al. 1990; Karrer et al. 1998). Transcriptional induction of UBC10 in Arabidopsis was recently detected following treatment with SA, MeJa, or ethylene and during the incompatible interaction with Alternaria brassicicola (Schenk et al. 2000) (Table 3). Finally, a putative metallo proteinase was induced by SNP treatment. This class of enzymes is not well known in plants but may have a role in plant cell death, as demonstrated for their mammalian counterparts (Beers et al. 2000).

The last group of sequences includes Arabidopsis unclassified proteins, which represent a large proportion (29.6\%) of NO-modulated transcripts. Among these, there are few that are expected to play a role in signal transduction on the basis of their automatically derived characteristics (Table 4).

The gene expression patterns produced by cDNA-AFLP analysis have been demonstrated to be equivalent to results obtained by Northern analysis (Bachem et al. 1996; Breyne et al. 2003). Expression profiles of replicate amplifications are highly comparable, with Person correlation coefficients between 0.80 and 0.90 (Breyne et al. 2003). These findings were also confirmed by RT-PCR experiments on selected cDNA fragments, which reproducibly showed them to be modulated by NO.

Comparison with microarray results from public databases and from published microarray analyses revealed that most NO-modulated genes are also affected in other stress-related conditions or in response to pathogens. However, many NOmodulated genes are absent from the EST-based microarray sources considered, namely the Stanford Microarray Database, and thus, they would not have been identified by this approach. It is interesting to note that, at the time of this analysis, $10 \%$ of the NO-modulated genes were not present in the EST database of Arabidopsis. Although at the time this manuscript was submitted only one differentially expressed cDNA was still not represented by any known EST in databases, the fact that most of the published or publicly available microarray analyses are carried out using sets of EST clones suggests that transcript profiling based on cDNA-AFLP analysis still represents today one of the best tools for fine gene discovery in species for which genome-wide arrays are not yet available.

Some of the identified NO-modulated genes will be the object of future research, designed to assess their possible functional role in resistance or cell death and to further elucidate the role of NO in plant resistance to pathogens.

\section{MATERIALS AND METHODS}

\section{Cultivation and treatment of Arabidopsis plants.}

Arabidopsis thaliana accession Columbia (Col-0) were grown in autoclaved potting mixture up to the stage of 10 to 12 true leaves in a growing chamber at $21^{\circ} \mathrm{C}$ during the day and $16^{\circ} \mathrm{C}$ during the night, with a photoperiod of $8 \mathrm{~h}$ to delay flowering. Plants were divided into two lots (15 plants each), and eight leaves per plant were fully infiltrated with either 1 mM SNP or distilled water, using a syringe with a $30 \mathrm{G}$ needle. Infiltrated leaves were collected at different times after treatment, i.e., $10 \mathrm{~min}, 1 \mathrm{~h}$, and $3 \mathrm{~h}$. Each sample of 40 leaves was collected and immediately frozen in liquid nitrogen. The experiment was repeated twice, and all similarly treated leaves were pooled. This leaf tissue was used for RNA preparation and cDNA-AFLP reactions. To follow the onset of cell death, an additional lot of plants was also infiltrated with SNP but not collected.

\section{RNA separation and cDNA-AFLP procedure.}

Total RNA was extracted from all samples according to Verwoerd and associates (1989). Poly(A) ${ }^{+}$RNA was isolated using oligotex columns (Qiagen, Hilden, Germany). Synthesis of double-strand cDNA was performed using the Superscript II reverse transcription kit (Invitrogen, Carlsbad, CA, U.S.A.), according to the manufacturer's instructions. The cDNA-AFLP technique was performed as described by Breyne and associates (2002). Briefly, mRNA was retrotranscribed, using a biotinylated oligo-dT primer. After cDNA digestion with Bst YI, the $3^{\prime}$ ends were captured on streptavidin magnetic beads (Dynal, Oslo, Norway). Digestion with MseI released the fragments that were amplified in the next steps. Adapters were ligated at each end of the restriction fragments. After a nonselective preamplification of the mixture, 32 selective amplifications were carried out with fluorescent labeling of the BstYI primer and one more selective nucleotide on each primer $(+1,+1)$. Selective amplifications were separated on $6 \%$ polyacrylamide gel in a $33 \times 61 \mathrm{~cm}$ vertical electrophoresis apparatus (Genomyx, Foster City, CA, U.S.A.) by running for $3 \mathrm{~h}$ at $2,700 \mathrm{~V}, 150 \mathrm{~W}$ at $50^{\circ} \mathrm{C}$. The gel image was acquired by a gel scanner apparatus (Genomyx) and was elaborated with the "Acquire" software (Beckman Coulter, Inc., Fullerton, CA, U.S.A.). Bands showing a marked variation in intensity in SNP-treated samples in comparison with the controls were excised from the gel, using a virtual grid (Genomyx) superimposed to the gel image for precise location of the band in the gel. The cDNAs were eluted from the bands in $100 \mu \mathrm{l}$ of sterile distilled water, and an aliquot of $5 \mu \mathrm{l}$ was used as a template for reamplification using nonlabeled primers identical to those employed for selective AFLP amplification. PCR products were purified with Centricon columns (Millipore, Bedford, MA, U.S.A.) and were subjected to direct sequencing without previous cloning. Sequence reactions were performed by the dideoxy termination method (Sanger et al. 1977).

\section{Sequence homology and microarray comparisons.}

Search for sequence homology was performed, using the TAIR and GenBank databases with the BLAST program (Altschul et al. 1997). The MIPS database was used to prepare a list of the full-length sequences for all the NO-modulated cDNAs. Full-length sequences were used to retrieve all the EST and the corresponding identification numbers from the TAIR database.

\section{RT-PCR analysis.}

RT-PCR was carried out on the same RNA used in the cDNA-AFLP experiments. First-strand cDNA, prepared by using Superscript RT (Invitrogen), was amplified with specific primers (20 to $25 \mathrm{bp}$ long) designed on each full-length cDNA sequence. Primers specific for Arabidopsis actin were used for normalization of the reaction. 


\section{ACKNOWLEDGMENTS}

We are very grateful to P. Breyne and colleagues for sharing the cDNA-AFLP technique before publication and to T. Gerats for his competent support and critical reading of the manuscript. This study was supported by a grant from the Ministry of University and Scientific Research, Project: "Role of nitric oxide in the hypersensitive reaction and in systemic acquired resistance in Arabidopsis thaliana."

\section{LITERATURE CITED}

Altschul, S. F., Madden T. L., Schaffer, A. A., Zhang, J. H., Zhang, Z., Miller, W., and Lipman, D. J. 1997. Gapped BLAST and PSI-BLAST: A new generation of protein database search programs. Nucleic Acid Res. 25:3389-3402.

Alvarez, M. A., Pennell R. I., Meijer P. J., Ishikawa A., Dixon R. A., and Lamb C. 1998. Reactive oxygen intermediates mediate a systemic signal network in the establishment of plant immunity. Cell 92:773-784.

Arnold, W. P., Mittal, C. K., Katsuki, S., and Murad, F. 1977. Nitric oxide activates guanylate cyclase and increases guanosine $3^{\prime}: 5^{\prime}$-cyclic monophosphate levels in various tissue preparations. Proc. Natl. Acad. Sci. U.S.A. 74:3203-3207.

Bachem, C. W., van der Hoeven, R. S., de Bruijn, S. M., Vreugdenhil, D., Zabeau, M., and Visser, R. G. 1996. Visualization of differential gene expression using a novel method of RNA fingerprinting based on AFLP: Analysis of gene expression during potato tuber development. Plant J. 9:745-753

Bachem, C. W. B., Oomen, R. J. F. J., and Visser, R. G. F. 1998. Transcript imaging with cDNA-AFLP: A step-by-step protocol. Plant Mol. Biol. 16:157-173.

Bachmair, A., Becker, F., Masterson, R. V., and Schell, J. 1990. Perturbation of the ubiquitin system causes leaf curling, vascular tissue alterations and necrotic lesions in a higher plant. EMBO (Eur. Mol. Biol. Organ.) J. 9:4543-4549.

Batz, O., Logemann, E., Reinold, S., and Hahlbrock K. 1998. Extensive reprogramming of primary and secondary metabolism by fungal elicitor or infection in parsley cells. Biol. Chem. 379:1127-1135.

Beers, E. P., Woffenden, B. J., and Zhao, C. 2000. Plant proteolytic enzymes: Possible roles during programmed cell death. Plant Mol. Biol. 44:399-415.

Belenghi, B., Acconcia, F., Trovato, M., Perazzolli, M., Bocedi, A., Polticelli, F., Ascenzi, P., and Delledonne, M. 2003. AtCYS1, a cystatin from Arabidopsis thaliana, suppresses hypersensitive cell death. Eur. J. Biochem. 270:1-12.

Beligni, M. V., Laxalt, A. M., and Lamattina, L. 1997. Putative role of nitric oxide in plant-pathogen interactions. Page 250 in: The Biology of Nitric Oxide, Part 6 S. Moncada, N. Toda, H. Maeda, and E. A. Higgs, eds. Portland Press, London.

Bendahmane, A., Kanyuka, K., and Baulcombe, D. 1999. The $x$ gene from potato controls separate virus resistance and cell death responses. Plant Cell 11:781-791.

Bent, A. 1996. Function meets structure in the study of plant disease resistance genes. Plant Cell 8:1757-1771.

Breyne, P., and Zabeau, M. 2001. Genome-wide expression analysis of plant cell cycle modulated genes. Curr. Opin. Plant Biol. 4:136-142.

Breyne, P., Dreesen, R., Vandepoele, K., De Veylder, L., Van Breusegem, F., Callewaert, L., Rombauts, S., Raes, J., Cannoot, B., Engler, G., Inze, D., and Zabeau, M. 2002. Transcriptome analysis during cell division in plants. Proc. Natl. Acad. Sci. U.S.A. 99:14825-14830.

Breyne, P., Dreesen, R., Cannoot, B., Rombaut, D., Vandepoele, K., Rombauts, S., Vanderhaeghen, R., Inze, D., and Zabeau, M. 2003. Quantitative cDNA-AFLP analysis for genome-wide expression studies. Mol. Gen. Genom. 269:173-179.

Buonaurio, R., Moretti, C., Caglioti, C., Arienti, G., and Palmerini, C. A. 2002. Preliminary investigations on the role of nitric oxide in systemic acquired resistance in Arabidopsis thaliana-Pseudomonas syringae pathosystem. Page 75 in: Book of Abstracts. 6th International Conference on Pseudomonas syringae Pathovars and Related Pathogens. Acquafredda di Maratea, Italy.

Chang, C., and Stadler, R. 2001. Ethylene hormone receptor action in Arabidopsis. Bioassays 23:619-627.

Cheong, Y. H., Chang, H. S., Gupta, R., Wang, X., Zhu, T., and Luan, S. 2002. Transcriptional profiling reveals novel interactions between wounding, pathogen, abiotic stress, and hormonal responses in Arabidopsis. Plant Physiol. 129:661-677.

Clark, D., Durner, J., Navarre, D. A., and Klessig D. F. 2000. Nitric oxide inhibition of tobacco catalase and ascorbate peroxidase. Mol. PlantMicrobe Interact. 13:1380-1384.
Clarke, A., Desikan, R., Hurst, R. D., Hancock, J. T., and Neill, S. J. 2000. NO way back: Nitric oxide and programmed cell death in Arabidopsis thaliana suspension cultures. Plant J. 24:667-677.

Clough, S. J., Fengler, K. A., Yu, I. C., Lippok, B., Smith, R. K., Jr., and Bent, A. F. 2000. The Arabidopsis dndl "defense, no death" gene encodes a mutated cyclic nucleotide-gated ion channel. Proc. Natl. Acad. Sci. U.S.A. 97:9323-9328.

Collinge, M., and Boller, T. 2001. Differential induction of two potato genes, Stprx 2 and StNAC, in response to infection by Phytophthora infestans and to wounding. Plant Mol. Biol. 46:521-529.

Cryns, V., and Yuan, J. 1998. Proteases to die for. Genes Dev. 12:1551-1570.

Dangl, J. L., and Jones, J. D. G. 2001. Plant pathogens and integrated defense responses to infection. Nature 411:826-833.

De Wit, P. J. G. M. 2002. Plant biology: On guard. Nature 416:801-803.

del Pozo, O., and Lam, E. 1998. Caspase and programmed cell death in the hypersensitive response of plants to pathogens. Curr. Biol. 8:11291132 .

Delledonne, M., Xia, Y., Dixon, R. A., and Lamb, C. 1998. Nitric oxide functions as a signal in plant disease resistance. Nature 394:585-588.

Delledonne, M., Zeier, J., Marocco, A., and Lamb, C. 2001. Signal interactions between nitric oxide and reactive oxygen intermediates in the plant hypersensitive disease resistance response. Proc Natl. Acad. Sci. U.S.A. 98:13454-13459.

Delledonne, M., Murgia, I., Ederle, D., Sbicego, P. F., Biondani, A., Polverari, A., and Lamb, C. 2002. Reactive oxygen intermediates modulate nitric oxide signaling in the plant hypersensitive disease-resistance response. Plant Physiol. Biochem. 40:605-610.

Delledonne, M., Polverari, A., Murgia, I. 2003. The functions of nitric oxide-mediated signaling and changes in gene expression during the hypersensitive response. Antioxid Redox Signal 5:33-41.

Desikan, R., Mackerness, S. A.-H., Hancock, J. T., and Neill, S. J. 2001. Regulation of the Arabidpsis transcriptome by oxidative stress. Plant Physiol. 127:159-172.

Durner, J., Wendehenne, D., and Klessig, D. F. 1998. Defense gene induction in tobacco by nitric oxide, cyclic GMP, and cyclic ADPribose. Proc. Natl. Acad. Sci. U.S.A. 95:10328-10333.

Durner, J., and Klessig, D. F. 1999. Nitric oxide as a signal in plants. Curr. Opin. Plant Biol. 2:369-374.

Durrant, W. E., Rowland, O., Piedras, P., Hammond-Kosack, K. E., and Jones, J. D. G. 2000. cDNA-AFLP reveals a striking overlap in racespecific resistance and wound response gene expression profiles. Plant Cell 12:963-977.

Ebel, J., and Mithofer, A. 1998. Early events in the elicitation of plant defense. PlanTable 206:35-348.

Genoud, T., Millar, A. J., Nishizawa, N., Kay, S. A., Schafer, E., Nagatani, A., and Chua, N. H. 1998. An Arabidopsis mutant hypersensitive to red and far-red light signals. Plant Cell 10:889-904.

Genoud, T., Buchala, A. J., Chua, N.-H., and Metraux, J. P. 2002. Phytochrome signalling modulates the SA-perceptive pathway in Arabidopsis. Plant J. 31:87-95.

Glazener, J. A., Orlandi, E. W., and Baker, C. J. 1996. The active oxygen response of cell suspensions to incompatible bacteria is not sufficient to cause hypersensitive cell death. Plant Physiol. 100:759-763.

Hausladen, A., and Stamler, J. S. 1998. Nitric oxide in plant immunity. Proc. Natl. Acad. Sci. U.S.A. 95:10345-10347.

Heath, M. C. 2000. Hypersensitive response-related death. Plant Mol. Biol. 44:321-334.

Jones, D. A., and Jones, J. D. G. 1997. The role of leucine-rich repeats proteins in plant defenses. Adv. Bot. Res. 24:90-167.

Karrer, E. E., Beachy, R. N., and Holt, C. A. 1998. Cloning of tobacco genes that elicit the hypersensitive response. Plant Mol. Biol. 36:681-690.

Klessig, D. F., Durner, J., Noad, R., Navarre, D. A., Wendehenne, D., Kumar, D., Zhou, J. M., Shah, J., Zhang, S., Kachroo, P., Trifa, Y., Pontier, D., Lam, E., and Silva, H. 2000. Nitric oxide and salicylic acid signaling in plant defense. Proc. Natl. Acad. Sci. U.S.A. 97:8849-8855.

Koizumi, M., Yamaguchi-Shinozaki, K., Tsuji, H., and Shinozaki, K. 1993. Structure and expression of two genes that encode distinct drought-inducible cysteine proteinases in Arabidopsis thaliana. Gene 129:175-182

Kumar, D., and Klessig, D. F. 2000. Differential induction of tobacco MAP kinases by the defense signals nitric oxide, salicylic acid, ethylene, and jasmonic acid. Mol. Plant-Microbe Interact. 13:347-351.

Lam, E., and del Pozo, O. 2000. Caspase-like protease involvement in the control of plant cell death. Plant Mol. Biol. 44:417-428.

Lam, E., Kato, N., and Lawton, M. 2001. Programmed cell death, mitochondria and the plant hypersensitive response. Nature 411:848-853.

Lamb, C., and Dixon, R. A. 1997. The oxidative burst in plant disease resistance. Annu. Rev. Plant Physiol. Plant Mol. Biol. 48:251-275.

Leshem, Y. Y., Wills, R. B. H., and Veng-Va Ku, V. 1998. Evidence for the function of the free radical gas—nitric oxide (NO) - as an endoge- 
nous maturation and senescence regulating factor in higher plants. Plant Physiol. Biochem. 36:825-833.

Levine, A., Pennel, R. I., Alvarez, M. E., Palmer, R., and Lamb, C. 1994. Calcium-mediated apoptosis in a plant hypersensitive disease resistance response. Curr. Biol. 6:427-437.

Mahalingam, R., Gomez-Buitrago, A. M., Eckardt, N., Shah, N., Guevara-Garcia, A., Day, P., Raina, R., and Fedoroff, N. V. 2003. Characterizing the stress/defense transcriptome of Arabidopsis. Genome Biol. 4:R20.

Maleck, K., Levine, A., Eulgem, T., Morgan, A., Schmid, J., Lawton, K A., Dangl, J. L., and Dietrich, R. A. 2000. The transcriptome of Arabidopsis thaliana during systemic acquired resistance. Nat. Genet. 26:403-410.

Marshall, H. E., Merchant, K., and Stamler, J. S. 2000. Nitrosation and oxidation in the regulation of gene expression. FASEB (Fed. Am. Soc. Exp. Biol.) J. 14:1889-1900.

Milioni, D., Sado, P. E., Stacey, N. J., Roberts, K., and McCann, M. C. 2002. Early gene expression associated with the commitment and differentiation of a plant tracheary element is revealed by cDNAamplified fragment length polymorphism analysis. Plant Cell $14: 2813-2824$

Navarre, D. A., Wendehenne, D., Durner, J., Noad, R., and Klessig, D. F. 2000. Nitric oxide modulates the activity of tobacco aconitase. Plant Physiol. 122:573-582.

Nürnberger, T., and Scheel, D. 2001. Signal transmission in the plant immune response. Trends Plant Sci. 6:372-379.

Pineda-Molina, E., and Lamas, S. 2001. Nitric oxide as a regulator of gene expression: Studies with the transcription factor proteins cJun and p50. Biofactors 15:113-115.

Qin, L., Overmars, H., Helder, J., Popeijus, H., van der Voort, J. R. Groenink, W., van Koert, P., Schots, A., Bakker, J., and Smant, G. 2000. An efficient cDNA-AFLP-based strategy for the identification of putative pathogenicity factors from the potato cyst nematode Globodera rostochiensis. Mol. Plant-Microbe Interact. 13:830-836.

Roperch, J. P., Lethrone, F., Prieur, S., Piouffre, L., Israeli, D., Tuynder, M., Nemani, M., Pasturaud, P., Gendron, M. C., Dausset, J., Oren, M., Amson, R. B., and Telerman, A. 1999. SIAh-1 promotes apoptosis and tumor suppression through a network involving the regulation of protein folding, unfolding, and trafficking: Identification of common effectors with p53 and p21 Waf1. Proc. Natl. Acad. Sci. U.S.A. 96:8070-8073.

Sanger, F., Nicklen, S., and Coulson, A. R. 1977. DNA sequencing with chain-termination inhibitors Proc. Natl. Acad. Sci. U.S.A. 74:5463-5467.

Saviani, E. E., Orsi, C. H., Oliveira, J. F., Pinto-Maglio, C. A., and Salgado, L. 2002. Participation of the mitochondrial permeability transition pore in nitric oxide-induced plant cell death. FEBS (Fed. Eur. Biochem. Soc.) Lett. 510:136-140.

Schaffer, R., Landgraf, J., Accerbi, M., Simon, V., Larson, M., and Wisman, E. 2001. Microarray analysis of diurnal and circadian-regulated genes in Arabidopsis. Plant Cell 13:113-123.

Scheideler, M., Schlaich, N. L., Fellenberg, K., Beissbarth, T., Hauser, N. C., Vingron, M., Slusarenko, A. J., and Hoheisel J. D. 2002. Monitoring the switch from housekeeping genes to pathogen defense metabolism in Arabidopsis thaliana using cDNA arrays. J. Biol. Chem. 277:10555-10651.

Schenk, P. M., Kazan, K., Wilson, I., Anderson, J. P., Richmond, T., Somerville, S. C., and Manners, J. M. 2000. Coordinated plant defense responses in Arabidopsis revealed by microarray analysis. Proc. Natl. Acad. Sci. U.S.A. 97:11655-11660.

Schmidt, H. H., and Walter, U. 1994. NO at work. Cell 78:919-925.

Seki, M., Narusaka, M., Ishida, J., Nanjo, T., Fujita, M., Oono, Y., Kamiya A., Nakajima, M., Enju, A., Sakurai, T., Satou, M., Akiyama, K., Taji, T., Yamaguchi-Shinozaki, K., Carninci, P., Kawai, J., Hayashizaki, Y., and Shinozaki, K. 2002. Monitoring the expression profiles of 7,000 Arabidopsis genes under drought, cold and high-salinity stresses using a full-length cDNA microarray. Plant J. 31:279-292.

Solomon, M., Belenghi, B., Delledonne, M., Menachem, E., and Levine, A. 1999. The involvement of cysteine proteases and protease inhibitor genes in the regulation of programmed cell death in plants. Plant Cell 11:431-444.

Song, F., and Goodman, R. M. 2001. Activity of nitric oxide is dependent on, but is partially required for function of, salicylic acid in the signaling pathway in tobacco systemic acquired resistance. Mol. PlantMicrobe Interact. 14:1458-1462.

Stamler, J. S., Singel, D. J., and Loscalzo, J. 1992. Biochemistry of nitric oxide and its redox-activated forms. Science 258:1898-1902.

Swidzinski, J. A., Sweetlove, L. J., and Leaver, C. J. 2002. A custom microarray analysis of gene expression during programmed cell death in Arabidopsis thaliana. Plant J. 30:431-446.

Takahashi, S., and Yamasaki, H. 2002. Reversible inhibition of photophosphorylation in chloroplasts by nitric oxide. FEBS (Fed. Eur. Biochem. Soc.) Lett. 512:145-148.

Van Camp W., Van Montagu, M., and Inze', D. 1998. $\mathrm{H}_{2} \mathrm{O}_{2}$ and NO: Redox signals in disease resistance. Trends Plant Sci. 3:330-334.

van der Biezen, E. A., Juwana, H., Parker, J. E., and Jones, J. D. G. 2000. cDNA-AFLP display for the isolation of Peronospora parasitica genes expressed during infection in Arabidopsis thaliana. Mol. PlantMicrobe Interact. 13:895-898.

Verwoerd, T. C., Dekker, B. M., and Hoekema, A. 1989. A small-scale procedure for the rapid isolation of plant RNAs. Nucleic Acid Res. $17: 2362$.

Voehringer, D. W., Hirschberg, D. L., Xiao, J., Lu, Q., Roederer, M Lock, C. B., Herzenberg, L. A., Steinman, L., and Herzenberg, L. A 2000. Gene microarray identification of redox and mitochondrial elements that control resistance or sensitivity to apoptosis. Proc. Natl. Acad. Sci. U.S.A. 97:2680-2685.

Wendehenne, D., Pugin, A., Klessig, D. F., and Durner, J. 2001. Nitric oxide: Comparative synthesis and signaling in animal and plant cells. Trends Plant Sci. 6:177-183.

\section{AUTHOR-RECOMMENDED INTERNET RESOURCES}

The European Bioinformatic Institute EPCLUSTAL cluster software: ep.ebi.ac.uk/EP/EPCLUST/

The Stanford Microarray Data Base: genome-www5.stanford.edu/ MicroArray/SMD/)

Munich Information Center for Protein Sequences Arabidopsis thaliana database: mips.gsf.de/proj/thal/

The Arabidopsis Information Resource (TAIR) database: www.arabidopsis. org

The National Center for Biotechnology Information GenBank database: www.ncbi.nlm.nih.gov 